\title{
Subsurface energy storage: geological storage of renewable energy - capacities, induced effects and implications
}

\author{
Sebastian Bauer ${ }^{1}$ (D) Andreas Dahmke ${ }^{1} \cdot$ Olaf Kolditz $^{2}$
}

Received: 19 May 2017/ Accepted: 28 September 2017/Published online: 14 October 2017

(C) The Author(s) 2017. This article is an open access publication

The transition of energy supply from mainly fossil sources to renewable energy sources is essential for mitigating climate change effects and preparing for a future of sustainable energy supply not relying on finite fossil resources. In Germany, this transition from fossil to renewable energy sources is termed "Energiewende" (energy transition) and further accelerated by the phase-out of nuclear energy until 2022 (BMWi 2015). However, energy supply from renewable sources like wind or solar power is subject to strong natural temporal fluctuations and therefore frequently does not match the instantaneous energy demand and energy base load. Energy storage is thus required, to dampen these fluctuations and to compensate for times of low power production. By taking up surplus power, energy storage also contributes to grid stability in times of high renewable energy production. The estimated yearly storage demand for Germany, assuming a large contribution of renewable energy, varies considerably, but may reach $50 \mathrm{TWh}$ of electrical energy (Klaus et al. 2010). Due to the fluctuating nature of renewable power production, storage is required on a wide range of time scales, ranging from seconds to months, as well as storage sizes, ranging from tens of kWh to tens of GWh (Luo et al. 2015).

This article is part of a Topical Collection in Environmental Earth Sciences on 'Subsurface Energy Storage', guest edited by Sebastian Bauer, Andreas Dahmke, and Olaf Kolditz.

Sebastian Bauer

sebastian.bauer@gpi.uni-kiel.de

1 Institute of Geosciences, Christian-Albrechts-University Kiel, Kiel, Germany

2 Helmholtz Centre for Environmental Research GmbH-UFZ, Leipzig, Germany
For long-term storage of large amounts of energy that arises from longer periods with excess energy provided by wind or sun, the geological subsurface may potentially provide the large storage capacities required for storage on daily to seasonal scales (Bauer et al. 2013). Suitable subsurface renewable energy storage options include compressed air energy storage (CAES), which may also be a short-term storage option on the hourly time scale; hydrogen gas, generated from electric power by hydrolysis; or synthetic methane gas, generated in turn from hydrogen. These gases can be stored in very large amounts of hundreds of millions of $\mathrm{m}^{3}$ STP (LBEG 2016) either in caverns or in porous formations. Energy in the form of heat may be stored in the subsurface using methods from geothermal applications (Kolditz et al. 2013). This includes near surface storage of heat (or cold) from residential or industrial areas, especially in urban settings, as well as high-temperature storage at up to $100{ }^{\circ} \mathrm{C}$ in the subsurface, which may provide also daily to seasonal heat storage. Experience from both open well systems and using borehole heat exchangers exists, however mainly in the lower temperature range (e.g. Mielke et al. 2014).

Although the geological subsurface offers large potential storage capacities, large achievable loading and unloading rates and a variety of suitable settings, also other ways of using the subsurface are already in place. These include shallow or deep geothermal applications for climatization of buildings, groundwater abstraction for drinking water purposes, mining of ores, coal or geomaterials, hydrocarbon production or disposal of hazardous materials or waste. Also protected entities, such as groundwater reservoirs, flora and fauna, and ultimately humans, have to be safeguarded when utilizing the geological subsurface, which may put restrictions on the implementation of certain types of subsurface use. In 
addition, competition for subsurface space, i.e. suitable geological formations, may impair their use as storage sites, as other types of use may already be in place or prohibit the use as storage site due to induced effects. Thus, methods are required for determining achievable storage capacities as well as charging and discharging rates of subsurface energy storage sites. Also, methods for assessing induced effects of geotechnical storage operations on other types of subsurface use and on protected entities are required. The ANGUS+ project is dedicated to contributing to these topics, in order to support the implementation and regulation of such geological storage sites. An overview of the ANGUS+ project results (Kabuth et al. 2017) is part of this topical collection.

The German government has acknowledged the demand for energy storage and initiated a research initiative for energy storage_- "Forschungsinitiative Energiespeicher" (Energy storage research initiative (BMWi et al. 2011) —as a joint effort of the Ministry of Education and Research (BMBF) and the Ministry for Economic Affairs and Energy (BMWi), which covers all types of storage methods and facilities. Within this priority research initiative, the ANGUS + project is funded as one of the three geoscientific research projects working on geological storage options. Also funded are the InSPEE project (e.g. Horváth et al. 2016), assessing storage capacities in salt caverns for Germany, and the H2STORE project (e.g. Feldmann et al. 2016), assessing hydrogen gas storage in former gas fields.

This topical collection presents first results of the ANGUS+ project and connected relevant research from other research projects.

Contributions to geological subsurface use and storage research can be structured into the main categories: (1) Parameterization of subsurface formations and induced processes for energy storage use; (2) development of process-oriented simulation tools; and (3) scenario simulations for specific storage options.

1. Assessing the opportunities and risks of subsurface use requires structural information on subsurface formations in terms of their occurrence and prevalence as well as their properties and induced effects regarding the use as potential storage sites. Here the papers by Dethlefsen et al. $(2016,2017)$ describe the parameterization required as well as a geostatistical analysis of available spatially distributed values for North Germany. Lüders et al. (2016) study induced gas phase evolution and Popp et al. (2016) temperature-dependent mass transfer. Berta et al. (2016), Westphal et al. (2017) and Lienen et al. (2017) study microbialmediated geochemical effects due to temperature changes and Kasina et al. (2017) and Pellizzari et al.
(2017) due to gas injection. Miao et al. (2016) investigate induced geotechnical effects.

2. A prognosis of storage dimensions and induced effects also requires adequate simulation tools, which represent the governing processes and allow for site-specific assessments. Herein, Boockmeyer and Bauer (2016) and Schulte et al. (2016) present new methods for the simulation of borehole heat exchangers, while Beyer et al. (2016) present methods for temperature-dependent phase transitions and Pfeiffer et al. (2016b) on simulator coupling. Nagel et al. (2016) present work on geomechanical coupling, while Mahmoudi et al. (2016) and Böttcher et al. (2017) simulate coupled effects for gas cavern storages. An information system, which incorporates all required surface and subsurface input data, is presented by Nolde et al. (2016).

3. Having parameterized the processes and the geological formations used and having developed suitable modelling tools, these models can be applied to assess options of subsurface energy storage, their monitoring and possible interactions with other types of use. The papers in this topical collection cover geothermal applications, site investigation and monitoring by Schelenz et al. (2017) as well as Wang and Bauer (2016), and applications to geomechanical effects during cavern storage by Khaledi et al. (2016) and monitoring aspects Köhn et al. (2016). Dimensioning and effects of porous formation gas storage are considered in Feldmann et al. (2016) and Pfeiffer et al. (2016a), who also test adequate monitoring methods in a virtual setting. Delfs et al. (2016) simulate induced brine migration, while al Hagrey et al. (2016) investigate methods for detection and monitoring of induced leakages.

As the work presented in this topical collection shows, the topic of subsurface energy storage and its implications for other types of use as well as the topic of subsurface spatial planning is a relatively new one. We therefore think that the development and provision of dedicated tools for the planning, dimensioning and impact assessment of subsurface energy storage are an imminent task for the scientific community. While prior work on gas storage techniques as well as geothermal applications provides a long-standing basis, new aspects, for example the high cyclicity of energy storage due to the intermittent nature of renewable resources, which induces mechanical, hydraulic and thermal effects, or high-temperature storage at up to $100{ }^{\circ} \mathrm{C}$ in subsurface thermal storage applications, which induce geomechanical and hydraulic changes, need to be experimentally quantified and reliable prognosis methods need to be developed. We think that only a thorough understanding of these effects and a corresponding analysis 
of their long-term and short-term risks, such as integrity of confining units, land subsidence or uplift, changes of groundwater flow fields as well as groundwater composition, are a prerequisite for the implementation of these energy storage techniques on the required large scale. However, only recently dedicated sessions at, for example, the German FHDGG conference ("Wärme-, Energie- und Kohlenstoffspeicherung im Untergrund"; Bayreuth 2014) or the European Geoscience Union ("ERE5.3 Process quantification and modelling in subsurface utilization", EGU 2016 and 2017, Vienna) have come up to specifically present this topic at international conferences. Generally, energy storage and subsurface use topics are integrated into sessions on geothermal use or larger-scale subsurface simulation approaches. We think that more dedicated conference sessions need to be established to allow for a clearer focus on these issues in the future.

In the long term, we think that treating the subsurface as a resource not only for energy production, but also for energy storage will require a subsurface planning approach. This subsurface planning approach should allocate specific types of use to individual subsurface formations and thus provide for enough subsurface space for priority uses, for example groundwater abstraction. We think that such an approach needs to be quantitative, i.e. it has to be able to assign for each type of use the corresponding subsurface spatial demand. Thus, also interactions between different types of use can be assessed, and their combination or mutual exclusion can be provided for in the planning process. Only by such an approach, a reliable and sustainable ecologic and economic use of the subsurface as a resource will be achieved. Such a quantitative approach is also transparent, as decisions on subsurface spatial needs are quantified, which we think will enhance public acceptance and thus support the installation of subsurface energy storage sites. This need becomes more obvious, as energy storage will become a central issue for the transformation of the energy system to renewable sources only. However, a further parameterization of the subsurface according to storage option needs, as well as methods for predicting and assessing the induced effects by such subsurface installations through (mainly numerical) modelling approaches, is therefore required to achieve these aims. This will be especially important when considering the linked risks and side effects, for example changes in groundwater temperature and composition or land subsidence, in relation to other options of the future energy system, as for example biomass, which is an energy technology also connected with environmental impacts such as soil compaction and high nutrient loads. Also here, we think that a transparent planning process for subsurface applications helps to obtain public acceptance. Tackling these tasks represents an effort for the wider geoscientific community, but also beyond, as technical aspects have to be considered and dedicated regulations have to be developed and implemented.

As becomes clear from this collection of scientific research papers, we think that an integrated and interdisciplinary approach to the topic of subsurface spatial planning and assessing geological storage options is required to prepare for a both economically and ecologically sustainable use of the subsurface resources.

Acknowledgements The editors owe many thanks to the authors of this topical collection, which include participants of the ANGUS+ project, but also from other projects and other parts of the world. We also gratefully acknowledge and appreciate the time and effort of the many international peer reviewers, who have reviewed the manuscripts submitted to this topical collection and thus contributed significantly to this collection of scientific papers. The editors also gratefully acknowledge funding provided by the German Ministry of Education and Research (BMBF) for the ANGUS+ project, Grant Number 03EK3022, as well as the support of the Project Management Jülich (PTJ). We are also grateful to the EES Journal Office at Leipzig for the professional and supportive handling of this topical collection.

Open Access This article is distributed under the terms of the Creative Commons Attribution 4.0 International License (http://crea tivecommons.org/licenses/by/4.0/), which permits unrestricted use, distribution, and reproduction in any medium, provided you give appropriate credit to the original author(s) and the source, provide a link to the Creative Commons license, and indicate if changes were made.

\section{References}

al Hagrey SA, Schäfer D, Köhn D, Wiegers CE, Chung D, Dahmke A, Rabbel W (2016) Monitoring gas leakages simulated in a near surface aquifer of the Ellerbek paleo-channel. Environ Earth Sci 75(10):1083. doi:10.1007/s12665-016-5784-1

Bauer S, Beyer C, Dethlefsen F, Dietrich P, Duttmann R, Ebert M, Feeser V, Görke U, Köber R, Kolditz O, Rabbel W, Schanz T, Schäfer D, Würdemann H, Dahmke A (2013) Impacts of the use of the geological subsurface for energy storage: an investigation concept. Environ Earth Sci 70(8):3935-3943. doi:10.1007/ s12665-013-2883-0

Berta M, Dethlefsen F, Ebert M, Gundske K, Dahmke A (2016) Surface passivation model explains pyrite oxidation kinetics in column experiments with up to 11 bars p $(\mathrm{O} 2)$. Environ Earth Sci 75(16):1175. doi:10.1007/s12665-016-5985-7

Beyer C, Popp S, Bauer S (2016) Simulation of temperature effects on groundwater flow, contaminant dissolution, transport and biodegradation due to shallow geothermal use. Environ Earth Sci 75(18):1244. doi: 10.1007/s12665-016-5976-8

BMWi (Bundesministerium für Wirtschaft und Energie) (2015) Die Energie der Zukunft-Vierter Monitoring-Bericht zur Energiewende. BMWi, Berlin

BMWi (Bundesministerium für Wirtschaft und Technologie), BMU (Bundesministerium für Umwelt, Naturschutz und Reaktorsicherheit), BMBF (Bundesministerium für Bildung und Forschung) (2011) Bekanntmachung einer gemeinsamen Initiative des Bundesministeriums für Wirtschaft und Technologie, des 
Bundesministeriums für Umwelt, Naturschutz und Reaktorsicherheit und des Bundesministeriums für Bildung und Forschung zur Förderung von Forschung und Entwicklung auf dem Gebiet von Energiespeichertechnologien (Förderinitiative Energiespeicher). Bundesanzeiger 75:1840-1843

Boockmeyer A, Bauer S (2016) Efficient simulation of multiple borehole heat exchanger storage sites. Environ Earth Sci 75(12):1-13. doi:10.1007/s12665-016-5773-4

Böttcher N, Görke U-J, Kolditz O, Nagel T (2017) Thermomechanical investigation of salt caverns for short-term hydrogen storage. Environ Earth Sci 76(3):98. doi:10.1007/s12665-017$6414-2$

Delfs J-O, Nordbeck J, Bauer S (2016) Upward brine migration resulting from pressure increases in a layered subsurface system. Environ Earth Sci 75(22):1441. doi:10.1007/s12665-016-6245-6

Dethlefsen F, Beyer C, Feeser V, Köber R (2016) Parameterizability of processes in subsurface energy and mass storage. Environ Earth Sci 75(10):1-25. doi:10.1007/s12665-016-5626-1

Dethlefsen F, Nolde M, Schäfer D, Dahmke A (2017) Basic parameterization of Schleswig-Holstein's shallow geological formations for numerical reactive transport simulations: representative groundwater compositions. Environ Earth Sci 76(2):59. doi:10.1007/s12665-016-6343-5

Feldmann F, Hagemann B, Ganzer L, Panfilov M (2016) Numerical simulation of hydrodynamic and gas mixing processes in underground hydrogen storages. Environ Earth Sci 75(16):1165. doi:10.1007/s12665-016-5948-z

Horváth PL, Donadei S, Schneider GS (2016) GIS-basierte Potenzialabschätzung für Salzkavernen und Aufbau des Informationssystem „Salz"im Projekt InSpEE. DGMK Frühjahrstagung 2016, Celle, Germany

Kabuth A, Dahmke A, Beyer C, Bilke L, Dethlefsen F, Dietrich P, Duttmann R, Ebert M, Feeser V, Görke U-J, Köber R, Rabbel W, Schanz T, Schäfer D, Würdemann H, Bauer S (2017) Energy storage in the geological subsurface: dimensioning, risk analysis and spatial planning: the ANGUS+ project. Environ Earth Sci 76(1):23. doi: 10.1007/s12665-016-6319-5

Kasina M, Bock S, Würdemann H, Pudlo D, Picard A, Lichtschlag A, März C, Wagenknecht L, Wehrmann LM, Vogt C, Meister P (2017) Mineralogical and geochemical analysis of Fe-phases in drill-cores from the Triassic Stuttgart Formation at Ketzin CO2 storage site before CO2 arrival. Environ Earth Sci 76(4):161. doi:10.1007/s12665-017-6460-9

Khaledi K, Mahmoudi E, Datcheva M, Schanz T (2016) Analysis of compressed air storage caverns in rock salt considering thermomechanical cyclic loading. Environ Earth Sci 75(15):1149. doi:10.1007/s12665-016-5970-1

Klaus T, Vollmer C, Werner K, Lehmann H, Müschen K (2010) Energieziel 2050: 100\% Strom aus erneuerbaren Quellen. Umweltbundesamt, Dessau-Roßlau

Köhn D, De Nil D, al Hagrey SA, Rabbel W (2016) A combination of waveform inversion and reverse-time modelling for microseismic event characterization in complex salt structures. Environ Earth Sci 75(18):1235. doi:10.1007/s12665-016-6032-4

Kolditz O, Jakobs L, Huenges E, Kohl T (2013) Geothermal energy: a glimpse at the state of the field and an introduction to the journal. Geotherm Energy 1:1. doi:10.1186/2195-9706-1-1

LBEG (2016) Untertage-Gasspeicherung in Deutschland. Erdöl Erdgas Kohle 132(11):409-417

Lienen T, Lüders K, Halm H, Westphal A, Köber R, Würdemann H (2017) Effects of thermal energy storage on shallow aerobic aquifer systems: temporary increase in abundance and activity of sulfate-reducing and sulfur-oxidizing bacteria. Environ Earth Sci 76(6):261. doi:10.1007/s12665-017-6575-z

Lüders K, Firmbach L, Ebert M, Dahmke A, Dietrich P, Köber R (2016) Gas-phase formation during thermal energy storage in near-surface aquifers: experimental and modelling results. Environ Earth Sci 75(21):1404. doi:10.1007/s12665-016-6181-5

Luo X, Wang J, Dooner M, Clarke J (2015) Overview of current development in electrical energy storage technologies and the application potential in power system operation. Appl Energy 137:511-536. doi:10.1016/j.apenergy.2014.09.081

Mahmoudi E, Khaledi K, von Blumenthal A, König D, Schanz T (2016) Concept for an integral approach to explore the behavior of rock salt caverns under thermo-mechanical cyclic loading in energy storage systems. Environ Earth Sci 75(14):1-19. doi:10. 1007/s12665-016-5850-8

Miao X-Y, Beyer C, Görke U-J, Kolditz O, Hailemariam H, Nagel T (2016) Thermo-hydro-mechanical analysis of cement-based sensible heat stores for domestic applications. Environ Earth Sci 75(18):1293. doi:10.1007/s12665-016-6094-3

Mielke P, Bauer D, Homuth S, Götz AE, Sass I (2014) Thermal effect of a borehole thermal energy store on the subsurface. Geothermal Energy 2(1):5. doi:10.1186/s40517-014-0005-1

Nagel T, Görke U-J, Moerman KM, Kolditz O (2016) On advantages of the Kelvin mapping in finite element implementations of deformation processes. Environ Earth Sci 75(11):1-11. doi:10. 1007/s12665-016-5429-4

Nolde M, Schwanebeck M, Dethlefsen F, Duttmann R, Dahmke A (2016) Utilization of a 3D webGIS to support spatial planning regarding underground energy storage in the context of the German energy system transition at the example of the federal state of Schleswig-Holstein. Environ Earth Sci 75(18):1284. doi:10.1007/s12665-016-6089-0

Pellizzari L, Lienen T, Kasina M, Würdemann H (2017) Influence of drill mud on the microbial communities of sandstone rocks and well fluids at the Ketzin pilot site for $\mathrm{CO} 2$ storage. Environ Earth Sci 76(2):77. doi:10.1007/s12665-016-6381-z

Pfeiffer WT, al Hagrey SA, Köhn D, Rabbel W, Bauer S (2016a) Porous media hydrogen storage at a synthetic, heterogeneous field site: numerical simulation of storage operation and geophysical monitoring. Environ Earth Sci 75(16):1177. doi: $10.1007 / \mathrm{s} 12665-016-5958-\mathrm{x}$

Pfeiffer WT, Graupner B, Bauer S (2016b) The coupled nonisothermal, multiphase-multicomponent flow and reactive transport simulator OpenGeoSys-ECLIPSE for porous media gas storage. Environ Earth Sci 75(20):1347. doi:10.1007/s12665016-6168-2

Popp S, Beyer C, Dahmke A, Koproch N, Köber R, Bauer S (2016) Temperature-dependent dissolution of residual non-aqueous phase liquids: model development and verification. Environ Earth Sci 75(11):1-13. doi:10.1007/s12665-016-5743-x

Schelenz S, Vienken T, Shao H, Firmbach L, Dietrich P (2017) On the importance of a coordinated site characterization for the sustainable intensive thermal use of the shallow subsurface in urban areas: a case study. Environ Earth Sci 76(2):73. doi:10. 1007/s12665-016-6331-9

Schulte DO, Welsch B, Boockmeyer A, Rühaak W, Bär K, Bauer S, Sass I (2016) Modeling insulated borehole heat exchangers. Environ Earth Sci 75(10):1-12. doi:10.1007/s12665-016-5638-x

Wang B, Bauer S (2016) Converting heterogeneous complex geological models to consistent finite element models: methods, development, and application to deep geothermal reservoir operation. Environ Earth Sci 75(20):1349. doi:10.1007/s12665016-6138-8

Westphal A, Kleyböcker A, Jesußek A, Lienen T, Köber R, Würdemann H (2017) Aquifer heat storage: abundance and diversity of the microbial community with acetate at increased temperatures. Environ Earth Sci 76(2):66. doi:10.1007/s12665016-6356-0 